\title{
Effect of Hydrogen Peroxide on Growth, Photosynthesis and Mineral Accumulation of Ficus deltoidea Var Deltoidea Jack
}

\author{
Nik-Nurnaeimah NM Nasir, Mohammad Moneruzzaman Khandaker*, and Nashriyah Mat \\ School of Agriculture Science \& Biotechnology, Faculty of Bioresources and Food Industry, Universiti Sultan \\ Zainal Abidin, Besut Campus, 22200 Besut, Terengganu, MALAYSIA \\ Corresponding author: moneruzzaman@unisza.edu.my
}

\begin{abstract}
Ficus deltoidea has received much attention in Malaysia and has become an international favorite due to its health-giving properties. However, F. deltoidea has been distinguished as a slow growing medicinal herb of 0.3 to 3.0 meters in height. The present study was carried out to investigate the effect of hydrogen peroxide on mineral accumulation, biological and chemical properties in Ficus deltoidea var. deltoidea. The Ficus deltoidea plants were spray-treated with 0 (control), 8, 16, 30 and $60 \mathrm{mM}$ hydrogen peroxide under field conditions during the growing period of March, 2015 to May, 2016 at field farm of faculty of Bioresources and Food Industry, UniSZA, Besut Campus. The experiment was arranged according to the completely randomized design (CRD) with 8 replications. The results showed that the application of $30 \mathrm{mM} \mathrm{H}_{2} \mathrm{O}_{2}$ increased plant height, leaf number, syconium number and net photosynthetic rate of $F$. deltoidea. The result indicated that hydrogen peroxide gave positive affected to the mineral uptake as it increase the mineral uptake including calcium, potassium, and sodium in leaf. From this study, it can be concluded that spraying 16 and $30 \mathrm{mM}$ of hydrogen peroxide once a week enhanced the growth and mineral uptake under field conditions.
\end{abstract}

Keywords: Ficus deltoidea, hydrogen peroxide, mineral, biological and chemical properties

\section{Introduction}

Ficus is from family Morcaceae one of the largest in plant genera with more than 750 described species distributed [1]. Ficus deltoidea is one of the herbal plants that can found in Malaysia, Africa, Indonesia and Southern Philippines the Malaysian forest have approximately 16\% (101) of known species of Ficus species. Each part of the plant have been recognised to possess medicinal properties since folkages including reducing sugar level in blood, decreasing blood pressure, migraine, increasing and recovering sexual desires, contracting the vagina after delivery, redusing cholesrrol and lipids, delaying menopause, toxin remover, nausea, piles painfever, and reducing the risk of cancer [2]. Ficus deltoidea contain 5 main active components including flavonoid, tannins, triterpenoids, proanthocyanins, and penols [3]. It has been reported to contain at least 25 flavonoids with major constituents' flavan-3-ol monomers, proanthocyanidins and C-linked flavone glycosidases. Currently two bioactive compounds were subjected possess in Ficus deltoidea to have $\alpha$ glucosidase inhibiton which are vitexin and isovitexin.

Hydrogen peroxide $\left(\mathrm{H}_{2} \mathrm{O}_{2}\right)$ is defined as reactive oxygen species (ROS) generated from molecular oxygen (O2) with relatively high stability and a long half-life. While according to Press et al. [4] $\mathrm{H}_{2} \mathrm{O}_{2}$ is an unstable compound used as an oxidizing and bleaching agent. Although the controlled cellular production of $\mathrm{H} 2 \mathrm{O} 2$ plays an important physiological role, high cellular level of $\mathrm{H}_{2} \mathrm{O}_{2}$ can produce carcinogenic effects and induced cell death. Superoxide radical $\left(\mathrm{O}_{2}\right)$ and hydrogen peroxide $\left(\mathrm{H}_{2} \mathrm{O}_{2}\right)$ are produced during cell metabolism in plant and in normal high amounts in various cell compartments, especially chloroplasts of higher plant, it is because chloroplasts are well equipped with defence enzymes against $\mathrm{O}_{2}$ and $\mathrm{H}_{2} \mathrm{O}_{2}$. Almeida et al. [5] stated that, $\mathrm{H}_{2} \mathrm{O}_{2}$ is one of the ROS produced in plants under both biotic and abiotic and play a key role against $\mathrm{O} 2$ derived cell 
toxicity. Chloroplasts also have an efficient $\mathrm{H} 2 \mathrm{O} 2$ scavenging system in which ascorbate peroxidase and glutathione reductase are of particular importance. $\mathrm{H}_{2} \mathrm{O}_{2}$ act as a messenger molecule involve in adaptive signalling, triggering tolerance against various abiotic stresses at low concentration but at high concentrations, it orchestrates programmed cell death [6]. Usually, abiotic stress such as drought will increase the production of ROS in the plant.

To the best of our knowledge, no research on the effect of hydrogen peroxide $\left(\mathrm{H}_{2} \mathrm{O}_{2}\right)$ on the growth and mineral accumulation of Ficus deltoidea has been reported so far and scarce information of Ficus deltoidea available in literature. In this project, we investigated the influenced of $\mathrm{H}_{2} \mathrm{O}_{2}$ in Ficus deltoidea on growth and mineral accumulation, properties. The novel findings of this study will have fundamental implication to improve photosynthetic capacity as well as productivity of this plant.

\section{Materials and Methods}

The studies were carried out at research plot at farm of Faculty of Bioresources and Food Industry, Universiti Sultan Zainal Abidin, Besut Campus under sunlight-proof shade house which covers approximately $40 \mathrm{~m} 2$ area between January, 2015 to October, 2016. Mother plant of Ficus deltoidea var. deltoidea was obtained from Kampung Sungai Nibong, Batu Pahat, Johor. Forty (40) uniform eight weeks old Ficus deltoidea cuttings were made from collected mother plant and transplanted into growing media containing $15 \mathrm{~kg}$ of BRIS soil (more than $90 \%$ sand) containing rotted empty oil palm fruit bunch and organic manure. Approximately ten grams of nutrients (N: P: K, at a ratio of 10: 10: 10) per plant was applied at 15-days before treatment applications. The plants were watered daily through sprinkler method during the whole growth stage (4 months). All of the experiments, which were conducted in the field, were performed under the following normal prevailing conditions: temperature $21-30{ }^{\circ} \mathrm{C}$, maximum PAR 500-1000 $\mu \mathrm{E} / \mathrm{m} 2 / \mathrm{s}$, and relative humidity of $60 \%-$ $90 \%$. Plants were sprayed manually with approximately $20 \mathrm{~mL}$ of the solution once a week using water (control), $8 \mathrm{mM}, 16 \mathrm{mM}, 30 \mathrm{mM}$ and $60 \mathrm{mM}$ of $\mathrm{H}_{2} \mathrm{O}_{2}$ by using sprayed bottle. In this study, a completely randomized design was used to design the pot experiment and each treatment had eight randomly distributed replicate.

The plant height, number of leaf, number of syconium, leaf area and net photosynthesis rate were measured during the plant growth and development. Plant height was individually measured from the base of the plant on the soil surface to the tip of the highest branch point. Each plant height was measured every 3 weeks and recorded in centimetres. The number of leaves and syconium were counted on each replicate and measured every 3 weeks. The data were recorded by using manual counting based on the observation. A matured leaves for each plant were selected and measured by using the Leaf Area Meter (Model Portable Laser CI-202, CID Bio-science, USA) with replicate data recorded. Photosynthesis data were recorded from 11 am to 2 pm every three weeks immediately after treatment application. Data for net photosynthesis rate was collected using a similar equipment, C1-340 Handled Photosynthesis System (CID Bio-Science, USA). In this study there were 7 kind of mineral and nutrient uptake were analysed including Arsenic (As), Antimony (Sb), Iron (Fe), Magnesium (Mg), Calcium (Ca), Sodium (Na), Potassium (K). Two part of the plant were selected for this study, which was leaf and syconium. The method used to analysed the mineral uptake was Neutron Activation Analysis (NAA) and this method was described by Nashriyah et ak. [7] with slightly modification.

Statistical analysis: Statistical analysis was performed by using SPSS 20 software (SPPS Inc). Repeated measures ANOVA were used to analyse data from plant physiological study.

\section{Results and Discussion}

\subsection{Growth and Photosynthesis}

Fig. 1 shows the plant 18 weeks after treated with different concentrations of $\mathrm{H}_{2} \mathrm{O}_{2}$. The result indicate that, there were significant differences in plant height, leaf number, and syconium number. Fig. 2(a) shows the plant height $(\mathrm{cm})$ of five different treatment of $\mathrm{H}_{2} \mathrm{O}_{2}$ within growth period starting at week 0 until week 18. It can be 
seen that from week 0 until week 18, all the plant show favourable increase in height. In week 3 until week 18, plant treated with $30 \mathrm{mM}$ gave the highest in plant height among others, with average of $19.69 \mathrm{~cm}$ (week 3), $24.56 \mathrm{~cm}$ (week 6), $38.81 \mathrm{~cm}$ (week 12) and $51.63 \mathrm{~cm}$ (week 18). While, the plant treated with $16 \mathrm{mM}$ and 60 $\mathrm{mM}$ indicated the second highest of the plant height when compare with the control $(0 \mathrm{mM})$. But, the plant treated with $8 \mathrm{mM}$ showed the lowest plant height when compared with the control plant. While, plant treated with $8 \mathrm{mM}$ resulted in slower increases in height starting at week 6 . At week 12 and onwards all plants showed significant differences with each other with the $\mathrm{p}$ value of $<0.05$. Our result on plant growth and development determined that $\mathrm{H}_{2} \mathrm{O}_{2}$ increased the growth and photosynthesis with the $30 \mathrm{mM}$ treatment showed the highest, and this result was supported by Lopez-Delgado et al. [8].

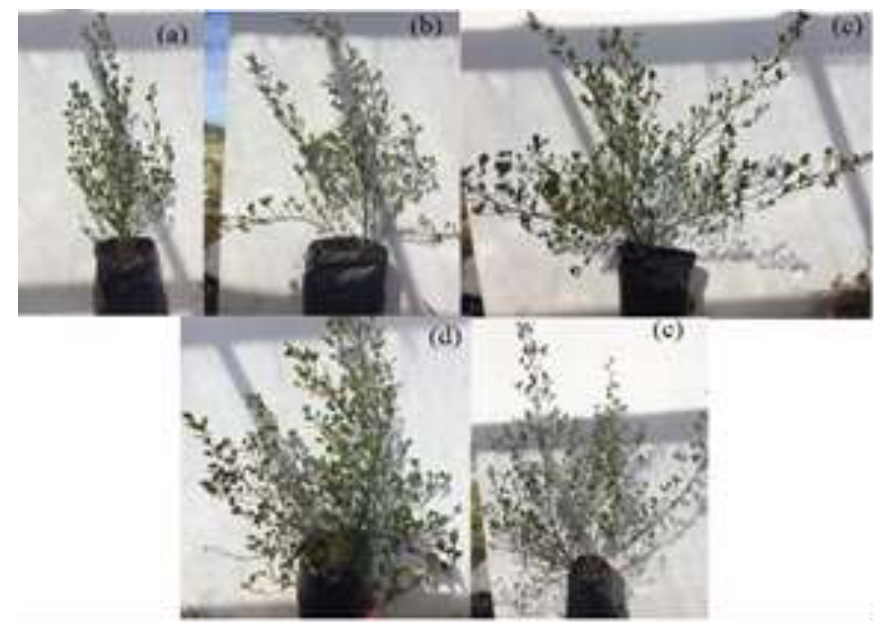

Fig. 1: The effect of different concentration of $\mathrm{H}_{2} \mathrm{O}_{2}$ on Ficus deltoidea var. deltoidea plant; (a) untreated plant, (b) plant treated with $8 \mathrm{mM}$, (c) plant treated with $16 \mathrm{mM}$, (d) plant treated with $30 \mathrm{mM}$, and (e) plant treated with $60 \mathrm{mM}$
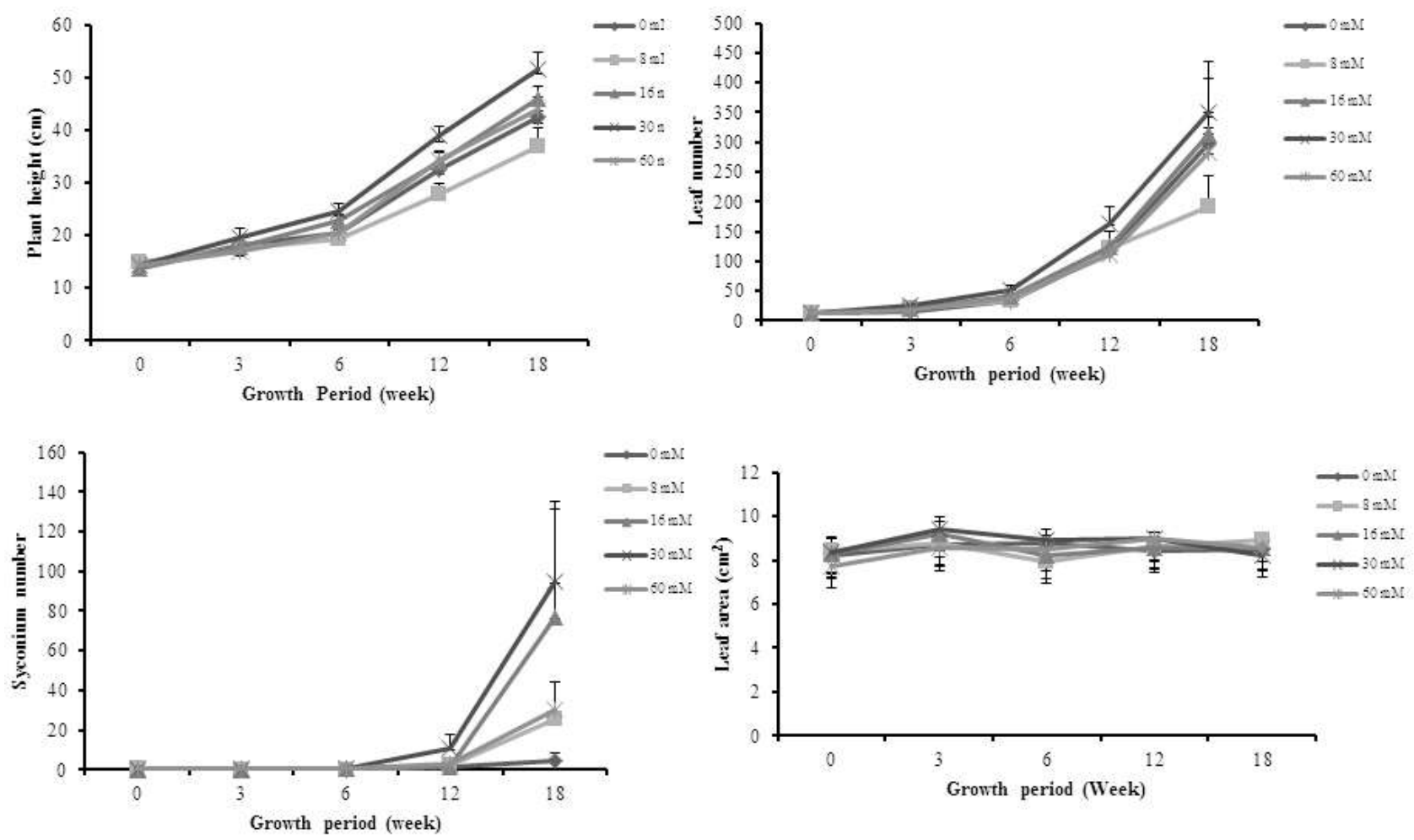

Fig. 2: The effect of $\mathrm{H}_{2} \mathrm{O}_{2}$ on (a) plant height, (b) leaf number, (c) syconium number, and (d) leaf area of Ficus deltoidea var. deltoidea plant with growth period 
As can be seen in the result, plant treated with $30 \mathrm{mM}$ of $\mathrm{H}_{2} \mathrm{O}_{2}$ showed the highest in plant height, which may be due to the positive role of $\mathrm{H}_{2} \mathrm{O}_{2}$ as plant growth stimulating substance. Rodriguez et al.[9] in their study suggested that, ROS (mainly $\mathrm{H}_{2} \mathrm{O}_{2}$ ) plays important positive role in plant growth development, and other physiological processes.

Fig. 2(b) presents the effect of $\mathrm{H}_{2} \mathrm{O}_{2}$ on number of leaf. It appears that, all the treated and untreated plant showed a gradual increment in number of leaf from week 0 until week 18. From five treatments, the treated plant with $30 \mathrm{mM}$ showed the highest number of leaf compare with other. However, treated plant with $8 \mathrm{mM}$ showed less number of leaf compared with other and it started to show differently at week 12 onwards. When analysed by using pairwise comparison with $95 \%$ confidence interval adjustment by Bonferroni correction, there were significant effects of $\mathrm{H}_{2} \mathrm{O}_{2}$ on number of leaf within each treatment based on week. The result indicate that, starting at week 3 , treated plant with $30 \mathrm{mM}$ showed significant difference with the treated plant of $0 \mathrm{mM}$ and $60 \mathrm{mM}$ treatment with average number of leaf 24 .

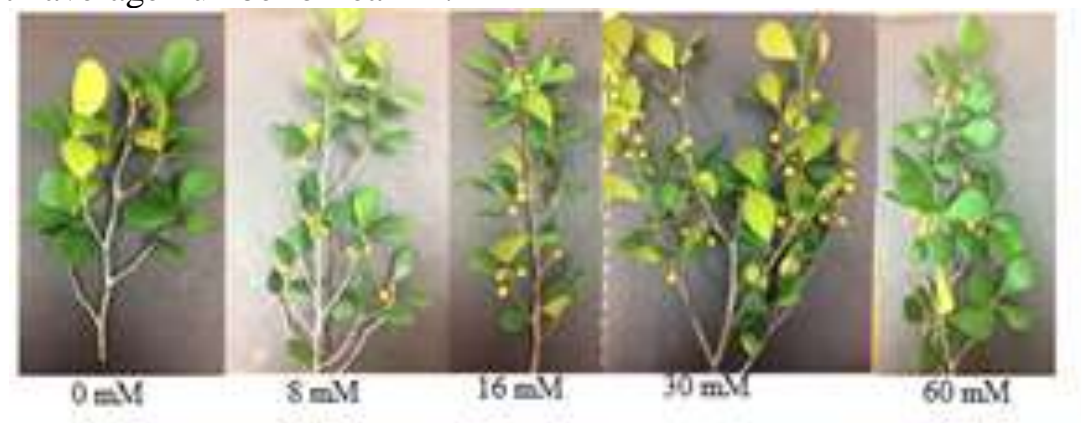

Fig. 3: The number of syconium of Ficus deltoidea var. deltoidea by different concentration of $\mathrm{H}_{2} \mathrm{O}_{2}$

Furthermore, Fig. 2(c) and 3 illustrate the effect of $\mathrm{H}_{2} \mathrm{O}_{2}$ on syconium number starting at week 0 until week 18. As seen in the graph, there was no different in syconium number during week 0 until week 6 . However, starting from week 6 and above, there was a drastical increase in syconium number for treated plant when compared with untreated plant. Treatment with $30 \mathrm{mM}$ shows the highest syconium number with the average means of 95 , followed by treatment with $16 \mathrm{mM}$ with average means of 77 and the lowest in syconium number was from untreated plant $(0 \mathrm{mM})$ with average means of 4 in week 18 . It seems that, there were significant difference effects of $\mathrm{H} 2 \mathrm{O} 2$ on the syconium number when compared between week 0 and week 3 for $0 \mathrm{mM}, 16$ $\mathrm{mM}$, and $30 \mathrm{mM}$, as only treated plant with $16 \mathrm{mM}$ have syconium. However, starting at week 12, treated plant with $30 \mathrm{mM}$ shows significant difference to all other treatment. Besides, the effect of $\mathrm{H}_{2} \mathrm{O}_{2}$ on leaf area $(\mathrm{cm} 2)$ was presented in Fig. 2(d), there was no different in leaf area among all the treated plant as the average was from $7 \mathrm{~cm} 2$ to $9 \mathrm{~cm} 2$ from week 0 until week 18 . This means that, there was no significant difference in treatment effect with $\mathrm{H}_{2} \mathrm{O}_{2}$.

The result showed that, $\mathrm{H}_{2} \mathrm{O}_{2}$ increases the number of leaf, leaf area and syconium on treated plant with 16 $\mathrm{mM}$ and $30 \mathrm{mM} \mathrm{H}_{2} \mathrm{O}_{2}$. This result was supported by the study of Li et al. [10], which indicated that treatment with $20-40 \mathrm{mM}$ of $\mathrm{H}_{2} \mathrm{O}_{2}$ significantly increase the number of adventitious roots and treatments with $10-50$ $\mathrm{mM}$ significantly increase the fresh weight of adventitious roots.

Fig. 4 indicate the effect of $\mathrm{H}_{2} \mathrm{O}_{2}$ on net photosynthesis rate. Among five treatments applied, $30 \mathrm{mM}$ shows the highest in net photosynthesis rate value with $3.96 \mu \mathrm{mol} / \mathrm{m} 2 / \mathrm{s}$ compared with the lowest net photosynthesis rate value, for control treatment, $8 \mathrm{mM}$, and 60 , at $\mathrm{mM} 2.10-2.50 \mu \mathrm{mol} / \mathrm{m} 2 / \mathrm{s}$. Furthermore, our results indicated that plant treated with $30 \mathrm{mM} \mathrm{H} \mathrm{O}_{2}$ showed the highest photosynthetic and transpiration rate which may be due to the $\mathrm{H}_{2} \mathrm{O}_{2}$ increasing the stomatal opening. 


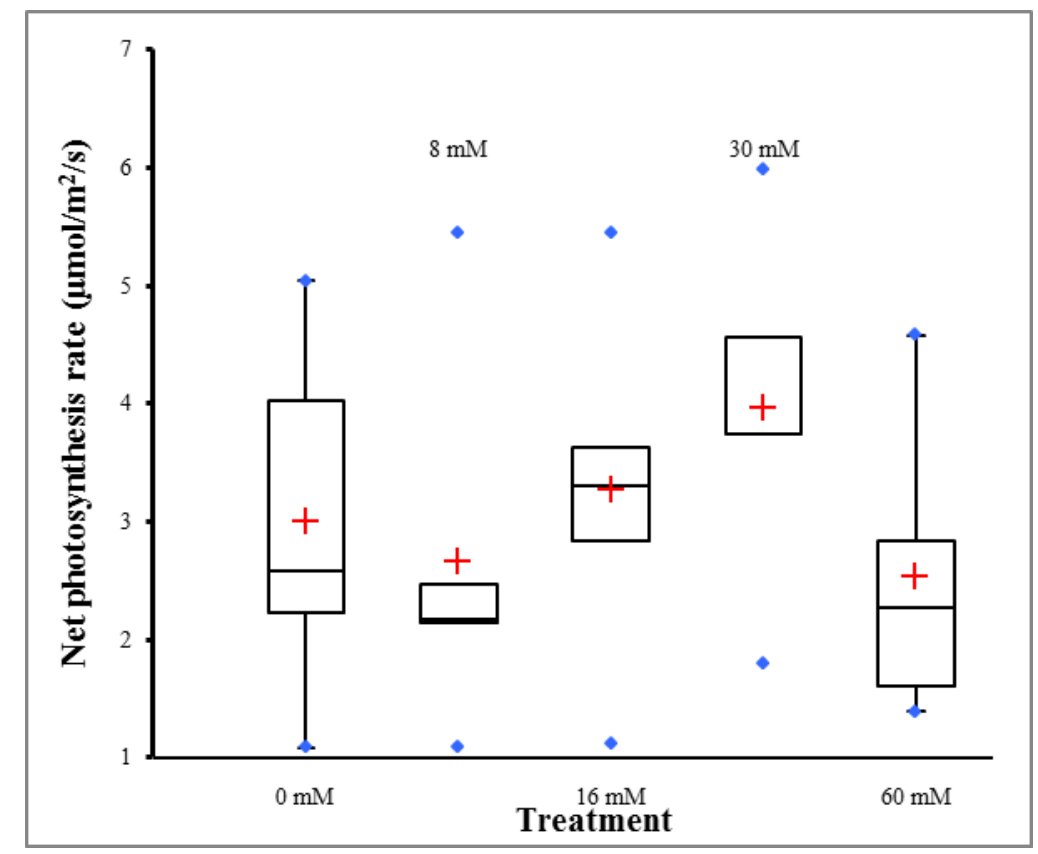

Fig. 4: The photosynthetic rate of Ficus deltoidea var. deltoidea by different concentration of $\mathrm{H}_{2} \mathrm{O}_{2}$.

It is a common signal that mediating both dark and ABA-induced stomatal closure [5]. Besides, $\mathrm{H}_{2} \mathrm{O}_{2}$ can be synthesized via several routes in plant cells such as electron transport processes during photosynthesis and respiration that generates basal levels of $\mathrm{H}_{2} \mathrm{O}_{2}$ [10], Our results related to photosynthesis are in agreement with the findings of Khandaker et al. [11] , who reported that exogenous $\mathrm{H}_{2} \mathrm{O}_{2}$ also increases photosynthetic rates and dry matter content of the leaves in wax apple under field conditions

\subsection{Mineral Accumulation}

TABLE I: The Effect of $\mathrm{H}_{2} \mathrm{O}_{2}$ on Mineral Accumulation in Leaf of Ficus deltoidea var. deltoidea

\begin{tabular}{lccc}
\hline & $\mathrm{Ca}(\%)$ & $\mathrm{K}(\%)$ & $\mathrm{Na}(\mu \mathrm{g} / \mathrm{g})$ \\
\hline $0 \mathrm{mM}($ Control) & $1.42(0.01) \mathrm{d}$ & $1.40(0.02) \mathrm{e}$ & $950(4.62) \mathrm{b}$ \\
& & & \\
$8 \mathrm{mM}$ & $1.75(0.02) \mathrm{a}$ & $1.72(0.01) \mathrm{b}$ & $670(2.88) \mathrm{e}$ \\
$16 \mathrm{mM}$ & $1.5(0.05) \mathrm{c}$ & $1.69(0.01) \mathrm{c}$ & $690(2.88) \mathrm{d}$ \\
$30 \mathrm{mM}$ & $1.66(0.01) \mathrm{b}$ & $1.79(0.01) \mathrm{a}$ & $740(1.15) \mathrm{c}$ \\
$60 \mathrm{mM}$ & $1.41(0.01) \mathrm{d}$ & $1.64(0.01) \mathrm{d}$ & $1220(2.31) \mathrm{a}$ \\
\hline
\end{tabular}

Data was present in Means (SE). Means within the same column of different line followed by the same letter, do not differ significantly according to LSD test at a $1 \frac{1}{4} 0.05$. Bars indicate $( \pm$ S.E $)$.

Table 1 shows the calcium $(\mathrm{Ca})$, potassium $(\mathrm{K})$, and sodium $(\mathrm{Na})$ accumulation in leaf of Ficus deltoidea var. deltoidea. The highest $\mathrm{Ca}$ uptake in leaf was in plant that was treated with $8 \mathrm{mM} \mathrm{H}_{2} \mathrm{O}_{2}(1.75 \%)$, followed by 30 $\mathrm{mM}$ treatment with $1.66 \%$, and the lowest was with $60 \mathrm{mM} \mathrm{H}_{2} \mathrm{O}_{2}$ treatment with $1.42 \%$.

From the result, it determined that, calcium increase in leaf at $8 \mathrm{mM}, 16 \mathrm{mM}$, and $30 \mathrm{mM}$ but decrease at higher concentration of $\mathrm{H}_{2} \mathrm{O}_{2}(60 \mathrm{mM})$, it was because suitable concentration of $\mathrm{H} 2 \mathrm{O} 2$ will trigger plant growth and it was supported by review from Xu et al.[12], the Salicylic acid (SA), $\mathrm{H}_{2} \mathrm{O}_{2}$ and $\mathrm{Ca}$ are recognized as signal molecules, and have been intensively investigated in plant adaptation to the changing environment, and induce plant tolerance to various biotic and abiotic stresses

The result indicates that, all the treated plants showed high $\mathrm{K}$ uptake contain in leaf compare with untreated plant. Plant treated with $60 \mathrm{mM} \mathrm{H}_{2} \mathrm{O}_{2}$ has the highest $\mathrm{Na}$ uptake in leaf $(1220 \mu \mathrm{g} / \mathrm{g})$, followed by untreated plant 
with $950 \mu \mathrm{g} / \mathrm{g}$ of $\mathrm{Na}$. The $\mathrm{Na}$ accumulation trend indicated that, there were decreases of $\mathrm{Na}$ in treated plant when low and moderate concentration of $\mathrm{H}_{2} \mathrm{O}_{2}$ were applied $\left(8 \mathrm{mM}-30 \mathrm{mM} \mathrm{H}_{2} \mathrm{O}_{2}\right)$, when compared with untreated plant, but there was a drastic increase of $\mathrm{Na}$ uptake in leaf when high concentration of $\mathrm{H}_{2} \mathrm{O}_{2}$ was applied (60 $\mathrm{mM})$. The pattern of $\mathrm{Na}$ uptake for treated plant showed that increasing the concentration of $\mathrm{H} 2 \mathrm{O} 2$ applied would increase the $\mathrm{Na}$ uptake. Our results showed that hydrogen peroxide application increased the accumulation of mineral content in the leaf of Mas cotek. Hameed and Farooq [13] determined that the application of exogenous $\mathrm{H}_{2} \mathrm{O}_{2}$ increase the plant growth as it provide more vigorous root system in wheat. Guzel \& Terzi, [14] also determined in his study of cultivar of Maize, plant treated with hydrogen peroxide caused the increases in mineral concentration compared to the control. Uchida et al. [15] stated that the application of $\mathrm{H}_{2} \mathrm{O}_{2}$ is a useful technique for agriculture. Hence, $\mathrm{H}_{2} \mathrm{O}_{2}$ also takes part in ABA-induced stomatal opening and closing [16]. As a conclusion, $\mathrm{H}_{2} \mathrm{O}_{2}$ gives positive influences if the suitable concentrations of $\mathrm{H}_{2} \mathrm{O}_{2}$ were used

\section{Conclusions}

From the above results, we concluded that the tested concentration of $\mathrm{H}_{2} \mathrm{O}_{2}$, particularly treatment with 16 and $30 \mathrm{mM}$ of $\mathrm{H}_{2} \mathrm{O}_{2}$ can improve the growth and development of Ficus deltoidea plant by increasing the plant height, number of leaf and syconium. Besides, the treatment with $\mathrm{H}_{2} \mathrm{O}_{2}$ also increases the net photosynthetic rate and mineral accumulation. It can be concluded that 16 and $30 \mathrm{mM} \mathrm{H}_{2} \mathrm{O}_{2}$ treatments were promising for enhancement of the growth, photosynthesis and accumulating mineral absorption of Ficus deltoidea var. deltoidea plant under sunlight-proof shade conditions.

\section{Acknowledgments}

This research was funded by KPT Grant (Project code: FRGS/2/2014/SG03/UNISZA/02/1). Authors would like to thank Universiti Sultan Zainal Abidin (UniSZA) for supporting this project.

\section{References}

[1] P, Pothasin, S. G. Compton, and P. Wangpakapattanawong, "Riparian Ficus tree communities: The distribution and abundance of riparian fig trees in Northern Thailand" PLoS ONE, vol.9, no.10,pp. 23-34, 2014.

[2] S. R. S. Aris, S. Mustafa, N. Ahmat, F. M. Jaafar, and R. Ahmad, "Phenolic Content and Antioxidant Activity of Fruits of Ficus deltoidea var Angustifolia sp" The Malaysian Journal of Analytical Sciences, vol.13, no. 2, pp.146-150., 2009.

[3] M. J. Oh, M. Abdul Hamid, S. Ngadiran, Y. K. Seo, M. R.,Sarmidi, and C. S. Park, "Ficus deltoidea (Mas cotek) extract exerted anti-melanogenic activity by preventing tyrosinase activity in vitro and by suppressing tyrosinase gene expression in B16F1 melanoma cells" Archives of Dermatological Research, vol.303, no. 3, pp.161-170, 2011.

[4] C. R. C. Press, B. Raton, . Mj, H. HCo, N. York, and A. Tl, “( $1 / 4$ D PR = 2 L: By Newton’s law of viscosity ( see viscosity ), the shear rate at the wall, g, (1), pp. 477-511, 2005.

[5] J. M. Almeida, F. Fidalgo, A. Confraria, A. Santos, H. Pires, I. Santos, "Effect of hydrogen peroxide on catalase gene expression, isoform activities and levels in leaves of potato sprayed with homobrassinolide and ultrastructural changes in mesophyll cells" Functional Plant Biolgy, vol. 32 no.8, pp.707-720, 2005.

[6] Q. Q. Ren, X. R. Huang, G. C. Liu, O. Y. Li, M. T. Jun, H.,Chen, ... W. Chen, A field-compatible technique using an electrochemical sensing microbundle for real-time and simultaneous in vivo measurement of hydrogen peroxide, nitric oxide, and pH under drought stress. Sensors and Actuators, B: Chemical, vol.220, pp. 743-748, 2015.

[7] M. Nashriyah, Z. Hamzah, M. Maskin, A. K. Wood, "Mineral Uptake by Taro (Colocasia esculenta) in Swamp Agroecosystem following Gramaxone®" (Paraquat). vol.. 3, no.1, pp. Pp.59-68, 2006.

[8] H. López-Delgado, H. A. Zavaleta-Mancera, M. E. Mora-Herrera, M. Vázquez-Rivera, F. X. Flores-Gutiérrez, I. M .Scott, "Hydrogen peroxide increases potato tuber and stem starch content, stem diameter, and stem lignin content." American Journal of Potato Research, vol. 82, no.12, pp.279-285,2005.

[9] A. A. Rodriguez, K. A. Grunberg, and E. L Taleisnik, "Reactive Oxygen Species in the Elongation Zone of Maize Leves Are Necessary for Leaf Extension” Plant Physiology, vol. 129 no.8, pp.1627-1632, 2014. 
[10] S. Li, L. Xue, S. Xu, H. Feng, L. An, "Hydrogen peroxide involvement in formation and development of adventitious roots in cucumber" Plant Growth Regulation, vol.52, no. 2, pp.173-180, 2007.

[11] M. M. Khandaker, A. N. Boyce, N. Osman, "The influence of hydrogen peroxide on the growth, development and quality of wax apple (Syzygium samarangense, [Blume] Merrill \& L.M. Perry var. jambu madu) fruits" Plant Physiology and Biochemistry, vol. 53, pp. 101-110, 2012.

[12] Q. Xu, X. Xu, Y. Zhao, K. Jiao, S. J. Herbert and L. Hao, "Salicylic acid, hydrogen peroxide and calcium-induced saline tolerance associated with endogenous hydrogen peroxide homeostasis in naked oat seedlings" Plant Growth Regul ation, vol. 54, no. 3, pp. 249-259, 2007.

[13] A. Hameed, and S. Farooq,"'Influence of exogenous application of hydrogen peroxide on root and seedling growth on wheat (Triticum aestivum L.)" International Journal of Agriculture and Biology, vol. 6, no. 2, pp. 366-369, 2004.

[14] S Guzel and R. Terzi, "Exogenous hydrogen peroxide increases dry matter production, mineral content and level of osmotic solutes in young maize leaves and alleviates deleterious effects of copper stress" Botanical Study, vol. 54, no.1, pp. 1-10, 2013.

[15] A. Uchida, T. Takabe, T. Takabe, T. Andre, and Jagendorf "Induction of Biosynthesis of Osmoprotectants in Higher Plants By Hydrogen Peroxide and Its Application To Agriculture. pp. 153-159, 2006.

[16] A. X. Huang, X. P. She, J. L. Zhao, and Y. Y. Zhang, "Inhibition of ABA-induced stomatal closure by fusicoccin is associated with cytosolic acidification-mediated hydrogen peroxide removal" Botanical Study, vol. 55, no.1, pp.:3343,2014 . 